\author{
菊地 貴子 $1,2 *$ ·大武 義人 ${ }^{1} \cdot$ 田中 敬二 ${ }^{2,3}$ *
}

\title{
Discoloration Phenomenon Induced by the Combination of Phenolic antioxidants and Hindered Amine Light Stabilizers
}

Takako KIKUCHI ${ }^{1 * 2}$, Yoshito OHTAKE ${ }^{1}$, Keiji TANAKA ${ }^{2,3^{*}}\left({ }^{1}\right.$ Chemicals Evaluation and Research Institute, Japan (1600, Shimo-takano, Sugito-machi, Kitakatsushika-gun, Saitama 345-0043, Japan. ${ }^{2}$ Department of Automotive Science, Kyushu University (744 Motooka, Nishi-ku, Fukuoka 819-0395, Japan. ${ }^{3}$ Department of Applied Chemistry, Kyushu University (744 Motooka Nishi-ku, Fukuoka 819-0395, Japan)*kikuchi-takako@ceri.jp and ktanaka@cstf.kyushu-u.ac.jp

Additives are generally mixed into polymeric materials to extend their lifetimes. However, the mixing of multiple additives may cause a negative synergy effect such as discoloration behaviors. We here report how the discoloration of a typical phenolic antioxidant, 2,6-di-tert-butyl-4-methylphenol(BHT), is promoted under the presence of hindered amine light stabilizers(HALS) on the basis of a temperature accelerated test. When BHT was used with HALS in $n$ decane solution at higher temperatures, quinone methide and stilbenequinone were produced via the oxidation of BHT, which can be catalyzed by titanium dioxide. This eventually leads to the discoloration of the reaction system. Interestingly, the discoloration phenomenon was further proceeded with increasing concentration of HALS and strength of HALS basicity. Similar results could be obtained even in polymer materials.

Key Words : Discoloration, Phenolic antioxidant, BHT, HALS, Titanium dioxide( $\left.\mathrm{TiO}_{2}\right)$

1. 緒

$\overline{\overline{\bar{D}}}$

高分子材料は機能性を長期維持するため, 酸化防止剂, 紫外線吸収剤, 熱安定剂や金属不活性剤等が複数種添加さ れており，その組み合わせによって正・負の相乗効果が発 現される.

フェノール系酸化防止剂は，ペルオキシラジカルを捕捉 する添加剤として，高分子材料には必要不可欠である。一 方, フェノール系酸化防止剂は熱・湿度・NOxガスや残 存触媒等, 様々な要因で, キノン系化合物へと変化し, 呈 色する ${ }^{1-10)}$. Figure 1はフェノール系酸化防止剂の代表 的な変色の反応機構である.フェノール系酸化防止剂は高 分子中でも酸化し, 黄変する11-13). 黄変の程度は無色ま たは白色から色相が黄方向へどの程度離れているかを示す

\footnotetext{
1 一般財団法人化学物質評価研究機構

（３45-0043 埼玉県北葛飾郡杉戸町下高野 1600）

2 九州大学大学院 統合領域学府 オートモーティブサイエンス専攻

3 九州大学大学院 工学研究院 応用化学部門

（ ₹ 819-0395 福岡市西区元岡 744）
}

Yellowness Index（YI）を指標に議論されている11-12). それに対して，ヒンダードアミン系光安定剤 (Hindered Amine Light Stabilizers: HALS) は2,2,6,6,-テトラメチル4-ピペリジンを基本骨格とし, 熱や光に安定で, 高分子材 料を着色しない.このため, HALSは光安定化能, ラジカ 儿捕捉能, 過酸化物分解能, 重金属捕捉能を有する多機能 安定剂として多用されている.

材料の設計指針として, 高性能化や高寿命化は当然である

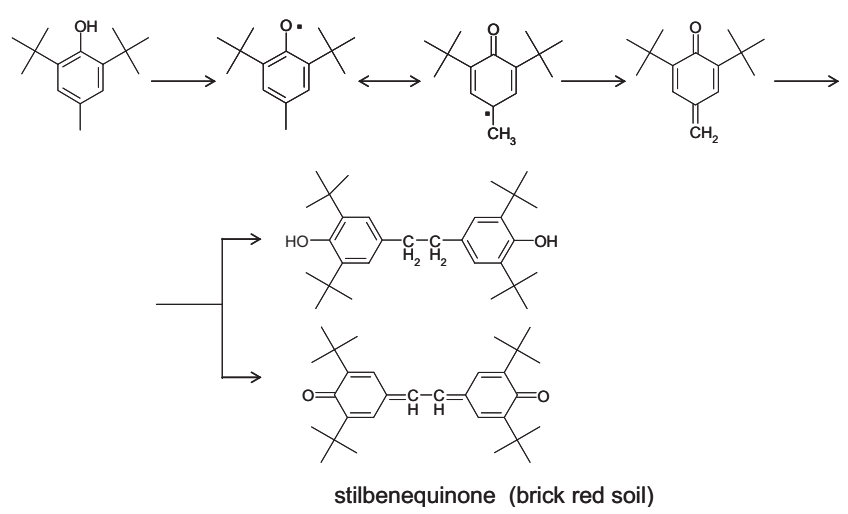

Figure 1 Possible discoloration pathways of $\mathrm{BHT}^{1-5)}$. 
が，これら機能性を長期維持するために，外観を損ねてはな らない. したがって，材料の変色を抑えることは品質管理上 重要な課題となっている. フェノール系酸化防止剤の変色現 象については, 系統的な研究が行われ, 十分な理解が進んで いる ${ }^{1-13)}$ ・ しかしながら，フェノール系酸化防止剤はHALS と併用されることが多いにもかかわらず14-20)，その際の変 色現象についての報告は少ない21,22).

本研究では，フェノール系酸化防止剂とHALSを併用 した際に生じる変色現象に着目した。はじめに，溶液系で 実験を行い, 分光学的解析から, その支配因子を検討した. 得られた結果に基づき，高分子材料中における変色現象の 説明を試みた。また，変色現象に及ぼす二酸化チタン $\left(\mathrm{TiO}_{2}\right)$ の効果についても調査した.

\section{2. 実験}

\section{1 供試料}

フェノール系酸化防止剂には和光純薬工業製 BHTを, HALSにはBASF ジャパン製 bis（2,2,6,6-tetramethyl-4piperidinyl） sebacate（以下HALS1）およびbis (1,2,2,6,6-pentamethyl-4-piperidinyl) sebacate（以下 HALS2）を，また， $\mathrm{TiO}_{2}$ には関東化学製ルチル型 $\mathrm{TiO}_{2}$ （ルチル）とアナターゼ型 $\mathrm{TiO}_{2}$ （アナターゼ）を用いた. これら添加剤および溶媒の $n$-デカンを各濃度 $5 \times 10^{-2}$ $\mathrm{mol} / \mathrm{L}$ になるよう密閉容器に導入し， $120{ }^{\circ} \mathrm{C}$ に保持するこ とで変色加速試験を行った。 $\mathrm{TiO}_{2}$ は溶媒に不溶であるた め，スターラーを用い，常時 $120 \mathrm{rpm}$ でかくはんした.

\section{2 変色物質の解析}

変色過程は目視および吸光度測定 $(J A S C O$ 製紫外・可視 分光光度計（UV/VIS） V-530）に基づき追跡した。 120 ${ }^{\circ} \mathrm{C}$ で 48 時間保持した上記試料を $\mathrm{MERCK}$ 製薄層クロマト グラフィー（TLC）プレートシリカゲル 60F 254 に負荷し， $n$-ヘキサン／酢酸エチル（80/20）混合溶液を用いて展開 した.分離した変色スポット部をシリカゲルごとかき取り, ジクロロメタンに溶解後，ガスクロマトグラフ質量分析 (GC/MS，アジレント・テクノロジー製 6890 series， 5975 inert, Agilent J\&W DB-5ms (長さ $30 \mathrm{~m}$, 内径 $0.25 \mathrm{~mm}$, 膜厚 $0.25 \mu \mathrm{m})$ ) を行った。また，水素炎イオン化検出器 付ガスクロマトグラフ（GC/FID，アジレント・テクノロ
ジー製HP6890）に基づきBHTの定量を行った.

\section{3 高分子材料中における変色現象}

試料として，製造段階で添加剤を除去した日本ポリプロ 製 PP（ポリプロピレン）ノバテックPPMA3を用いた. 使用前，ペレットの状態で 16 時間ソックスレー抽出を行 つた. Table 1はPP と添加剤の配合をまとめた表である. $200{ }^{\circ} \mathrm{C}$ に加熱したオープンロールを用いPPにBHT, HALS1, $\mathrm{TiO}_{2}$ を混練り後, $200{ }^{\circ} \mathrm{C} 3$ 分で $2 \mathrm{~mm}$ 厚プレスシ ートを作製した。強制循環式空気加熱老化試験機を用い, $90{ }^{\circ} \mathrm{C}$ で最長 28 日間の熱処理を行うことで PP シートの変色

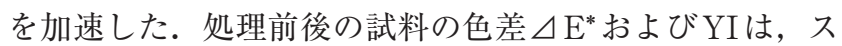
ガ試験機製多光源分光測色計 MSC-IS-2DHを用いて評価し た。また，PPシートを冷凍粉砕で微粉末化し，ジクロロ メタンにて 16 時間ソックスレー抽出後, 抽出物を $n$-デカ ンに溶解した。抽出物はUV/VIS 測定を，抽出後のPPは 風乾後，フーリエ変換赤外分光（バリアン製FT-IR FTS6000, UMA-500）測定を減衰全反射（ATR）法で行った。

\section{3. 結 果 と 考 察}

\section{1 目視による外観観察}

Table 2 は種々の添加剂を加えた $n$-デカン溶液に熱処理 を行った際の目視観察の結果である. BHT・HALS1・ア ナターゼを併用した系では 12 時間後から，また，BHT・ HALS1 を併用した系では 24 時間後から黄変が認められ た。同じ $\mathrm{TiO}_{2}$ でも結晶系の異なるルチルを添加した場合 には，BHT・HALS1の変色は24時間以降しか確認され なかった. 48 時間熱処理後のBHT ・ HALS1・ルチルお よび BHT・HALS1・アナターゼを遠心分離すると, $n$-デ カン層のみが着色しており， $\mathrm{TiO}_{2}$ は白色粉末のままであ った。一方，添加剤単体，また，BHTあるいはHALS1に $\mathrm{TiO}_{2}$ のみを加えた系では, 熱処理前後で変色は認められ なかった。これらの結果は，BHTとHALS1を併用した場 合のみ変色が発現すること, また, $\mathrm{TiO}_{2}$ は上記変色現象 に対し触媒として作用することを示している。

\section{2 分光学的評価}

Figure 2 は $120{ }^{\circ} \mathrm{C} て ゙ 48$ 時間熱処理を行った BHT・ HALS1 およびBHT・HALS1に $\mathrm{TiO}_{2}$ を併用した系の

Table 1 Composition of polypropylene compounds used

\begin{tabular}{ccccccccc}
\hline \multirow{2}{*}{ Ingredients } & \multicolumn{7}{c}{ Weight per hundred polypropylene } \\
\cline { 2 - 9 } & PP1 & PP2 & PP3 & PP4 & PP5 & PP6 & PP7 & PP8 \\
\hline Polypropylene & 100 & 100 & 100 & 100 & 100 & 100 & 100 & 100 \\
\hline BHT & - & 0.5 & - & - & - & 0.5 & 0.5 & 0.5 \\
\hline HALS1 & - & - & 0.5 & - & - & 0.5 & 0.5 & 0.5 \\
\hline Rutile & - & - & - & 1 & - & - & 1 & - \\
\hline Anatase & - & - & - & - & 1 & - & - & 1 \\
\hline
\end{tabular}


Table 2 Visual observation of additive $n$-decane solutions with naked eye

\begin{tabular}{llccc}
\hline \multirow{2}{*}{ Samples } & \multicolumn{4}{c}{ Heating time } \\
\cline { 2 - 5 } & $0 \mathrm{~h}$ & $12 \mathrm{~h}$ & $24 \mathrm{~h}$ & $48 \mathrm{~h}$ \\
\hline BHT·HALS1 & clear & clear & Faint yellow & yellow \\
\hline BHT·HALS1·anatase & clear & Faint yellow & Saffron yellow & Saffron yellow \\
\hline BHT·HALS1·rutile & clear & clear & Faint yellow & yellow \\
\hline BHT & clear & clear & clear & clear \\
\hline HALS 1 & clear & clear & clear & clear \\
\hline Anatase & clear & clear & clear & clear \\
\hline Rutile & clear & clear & clear & clear \\
\hline BHT·anatase & clear & clear & clear & clear \\
\hline HALS1·anatase & clear & clear & clear & clear \\
\hline
\end{tabular}

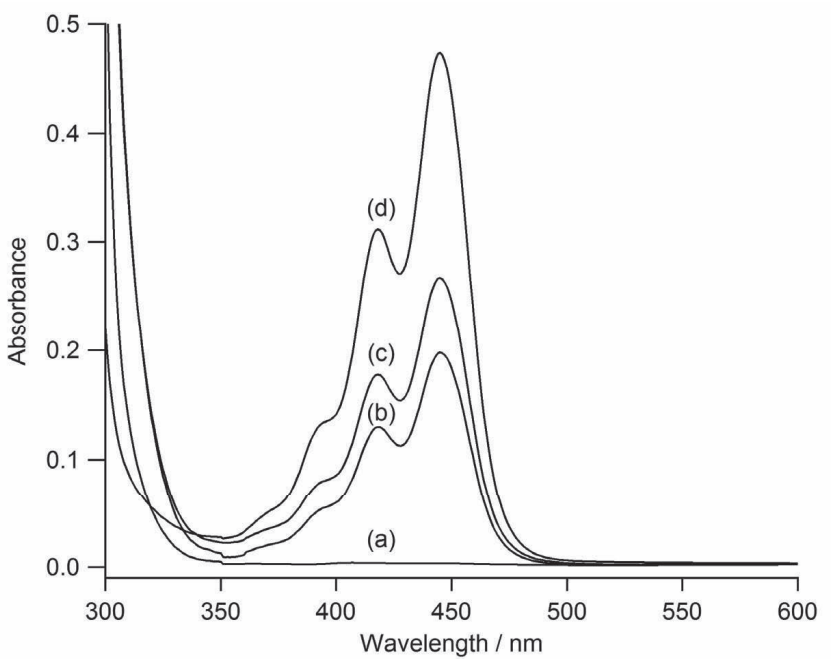

Figure 2 UV/VIS spectra; (a) pristine (BHT-HALS1), (b) $(\mathrm{BHT} \cdot \mathrm{HALS1})\left(10^{-1}\right.$ dilution) after heating at $120^{\circ} \mathrm{C}$ for $48 \mathrm{~h}$, (c) (BHT $\cdot \mathrm{HALS} 1 \cdot$ rutile $)\left(20^{-1}\right.$ dilution) after heating at $120^{\circ} \mathrm{C}$ for $48 \mathrm{~h}$, and (d) (BHT.HALS1. anatase) $\left(10^{-2}\right.$ dilution) after heating at $120^{\circ} \mathrm{C}$ for $48 \mathrm{~h}$.

UV/VIS 吸収スペクトルである，比較のため，熱処理前の スペクトルも示している． $\mathrm{TiO}_{2}$ 添加の有無にかかわらず,

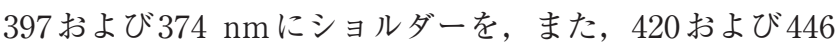
$\mathrm{nm}$ に吸収極大を有するピークが観測された。熱処理前の スペクトルには，350から500 nmの波長範囲で吸収ピー クが観測されていない。これらのことから， BHT・ HALS1 併用系に熱処理を行うと, 可視領域に吸収を有す る物質が生成すると結論できる。また，熱処理後のBHT， HALS1，ルチル，アナターゼ単体执よびBHT・アナター ゼならびにHALS1・アナターゼ併用系の場合にも $350 \mathrm{~nm}$ 以上の領域に吸収は認められなかった。以上の結果は, Table 2に示した目視観察の結果とよく対応している.

熱処理に伴う吸収強度は $\mathrm{TiO}_{2}$ の有無だけでなく，その 結晶形態にも依存した４価のTiはフェノール系酸化防止 剂と反応し，500～650 $\mathrm{nm}$ に吸収を有する錯体を形成し， 変色を生じることが知られている ${ }^{10)}$. しかしながら，こ こで観測された熱処理生成物の吸収波長範囲は 350 ～500 $\mathrm{nm}$ であり, $\mathrm{Ti}$ 錯体の波長範囲と異なっていることから，

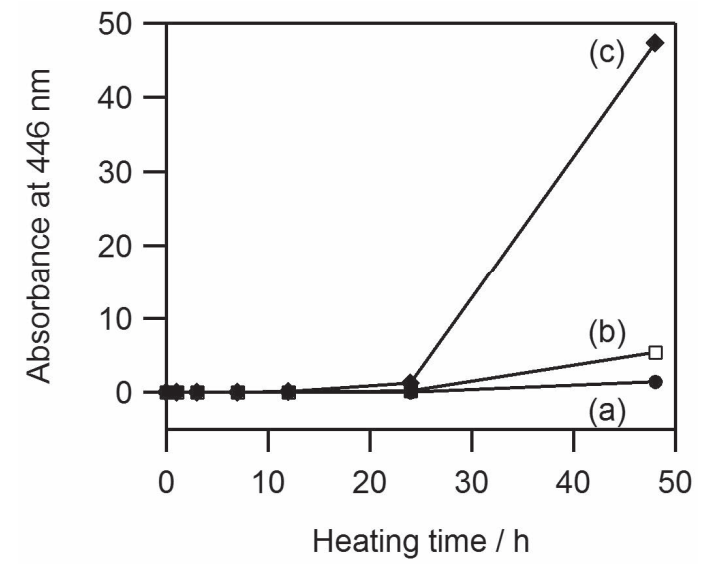

Figure 3 Relationship between absorbance at $446 \mathrm{~nm}$ and heating time for (a) (BHT.HALS1), (b) (BHT·HALS1 • rutile), and (c) (BHT $\cdot$ HALS1 $\cdot$ anatase $)$.

変色を誘因する物質は Ti錯体ではないと考えて良い。

Figure 3 はBHT・HALS1, BHT・HALS1・ルチルお よびBHT・HALS1・アナターゼ系における最大吸収波長 $(\lambda \max ) 446 \mathrm{~nm}$ での吸光度と熱処理時間の関係である。 ただし，吸光度が 1.0 以上であった試料は $n$-デカンで希釈 し, 希积倍率を乗じた值を吸光度としてプロットしている. 熱処理を 24 時間以上施すと $\mathrm{TiO}_{2}$ の添加効果は明確とな り，その程度はアナターゼの方が顕著であった。

\section{3 変色物質の同定}

$120{ }^{\circ} \mathrm{C} 48$ 時間熱処理を行ったBHT・HALS1・アナタ 一ゼの $n$-デカン溶液をTLCで分離精製した。 $\mathrm{R}_{\mathrm{f}}$ (Rate of flow value）值が $0.96 ， 0.91 ， 0.78 ， 0.35$ および 0.13 の位置 に黄色スポットが確認された。特に $\mathrm{R}_{\mathrm{f}}=0.96,0.91$ および 0.13 のスポットは濃黄色であり, $\mathrm{R}_{\mathrm{f}}=0.78$ および 0.35 のス ポットは薄黄色であった. 各々の黄色スポットをシリカゲ ルごと採取，ジクロロメタンに溶解し，GC/MS 測定を行 った．Figure 4はその結果であり，BHT㧍よびBHT dimer 以外に 3,3',5,5'-tetra-tert-butyl-4,4'-stilbenequinone (以下スチルベンキノンと略記)，2,6-di-tert-butyl-4methylidene-2,5-cyclohexadien-1-one（以下キノンメチド 
Table 3 Identification of substances, which were fractionated by thin layer chromatography, in an additive solution of BHT, HALS1 and anatase after heating at $120^{\circ} \mathrm{C}$ for $48 \mathrm{hrs}$ on the basis of gas chromatography-mass spectrometry

\begin{tabular}{|c|c|}
\hline TLC yellow spots & Identification of substances \\
\hline $\mathrm{R}_{\mathrm{f}}=0.96$ & $\begin{array}{l}\text { BHT } \\
\text { BHTdimer } \\
\text { 3,3',5,5'-tetra-tert-butyl-4,4'-stilbenequinone (stilbenequinone) } \\
\text { 2,6-di-tert-butyl-4-methylidene-2,5-cyclohexadien-1-one } \\
\text { (quinone methide) } \\
\text { 2,6-di-tert-butyl-4-methylidene-2,5-cyclohexadien-1,4-dione } \\
\text { (benzoquinone) }\end{array}$ \\
\hline $\mathrm{R}_{\mathrm{f}}=0.91$ & $\begin{array}{l}\text { stilbenequinone } \\
\text { quinone methide } \\
\text { Benzoquinone } \\
\text { 3,5-di-tert-butyl-4-hydroxybenzaldehyde }\end{array}$ \\
\hline $\mathrm{R}_{\mathrm{f}}=0.78$ & $\begin{array}{l}\text { quinone methide } \\
\text { 3,5-di-tert-butyl-4-hydroxybenzaldehyde } \\
\text { 2,6-di-tert-butyl-4-nitrophenol }\end{array}$ \\
\hline $\mathrm{R}_{\mathrm{f}}=0.35$ & $\begin{array}{l}\text { quinone methide } \\
\text { 3,5-di-tert-butyl-4-hydroxybenzaldehyde } \\
\text { 2,6-di-tert-butyl-4-nitrophenol }\end{array}$ \\
\hline $\mathrm{R}_{\mathrm{f}}=0.13$ & $\begin{array}{l}\text { quinone methide } \\
\text { 3,5-di-tert-butyl-4-hydroxybenzaldehyde } \\
\text { 2,6-di-tert-butyl-4-nitrophenol }\end{array}$ \\
\hline
\end{tabular}

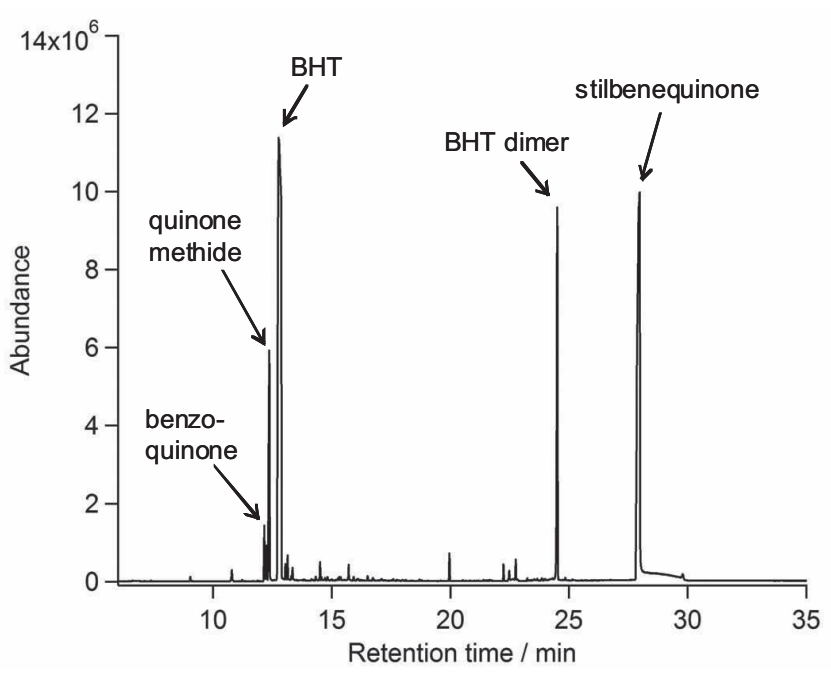

Figure $4 \mathrm{GC} / \mathrm{MS}$ total ion chromatogram for a spot with TLC $\mathrm{R}_{\mathrm{f}}=0.96$ from a sample $(\mathrm{BHT} \cdot \mathrm{HALS} 1 \cdot$ anatase $)$ after heating at $120^{\circ} \mathrm{C}$ for $48 \mathrm{~h}$.

と略記)，2,6-di-tert-butyl-4-methylidene-2,5-cyclohexadien1,4-dione（以下ベンゾキノンと略記）が検出されている. Table 3 は各スポットから検出された成分をまとめた表で ある. 濃黄色スポットである $\mathrm{R}_{\mathrm{f}}=0.96$ から検出されたス チルベンキノンの $\lambda{ }_{\max }$ は $452 \mathrm{~nm}$, また, ベンゾキノンの 可視光領域の $\lambda$ max は443 nmであり ${ }^{11)}$, UV/VIS 測定の結 果と良く対応する。したがって，BHTとHALSを併用した場 合における変色の要因は，熱処理によってBHTが酸化しス チルベンキノンやベンゾキノン等の有色物質を生成したため と結論できる．これは，大勝がHALSがニトロソニウムを生 成しBHTを酸化するという結果と一致する ${ }^{21,22)}$.

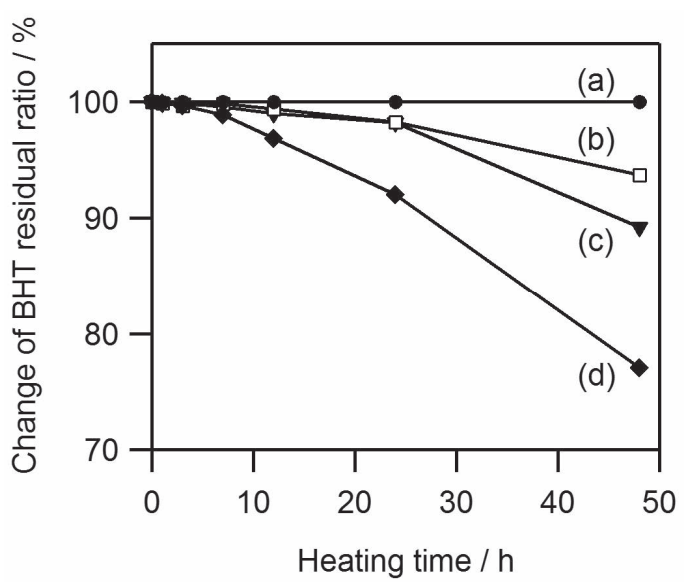

Figure 5 Time-change of BHT residual ratio after heating at $120^{\circ} \mathrm{C}$ for; (a) BHT, (b) (BHT.HALS1), (c) (BHT. $\mathrm{HALS} 1 \cdot$ rutile $)$, and $(\mathrm{d})(\mathrm{BHT} \cdot \mathrm{HALS} 1 \cdot$ anatase $)$.

BHT 単体に同条件で熱処理を行っても変色せず，また， キノン系化合物等も検出されなかった. BHT ・ HALS1お よび BHT ・ HALS1・ルチルの GC/MS 分析の結果, $\mathrm{BHT}$ ・HALS1・アナターゼ同様にキノン系化合物の生成 が確認された。

\subsection{BHTの転換}

BHT はHALS1の存在下 $120{ }^{\circ} \mathrm{C}$ の熱処理でキノン系化合 物に変換される。Figure 5 は BHT単体, BHT・ HALS1・ルチルおよびBHT ・ HALS1 ・アナターゼにお けるBHT残存率の時間依存性である。BHT単体の場合, 残存率は 48 時間の熱処理においても変化しなかったが, HALS1 を併用すると, BHT残存率は時間とともに減少し 


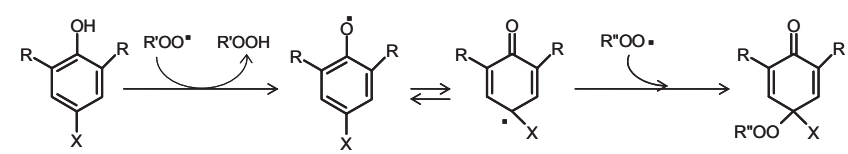

Figure 6 A mechanism of $\mathrm{BHT}$ as a radical scavenger.

た。この結果は，これまでに述べた実験結果とよく一致し ている. BHTはHALS1存在下で加熱されると, Figure 6 に示したラジカル捕捉剤としての反応ではなく, Figure 1 に示すキノン系化合物に変換される. BHT ・ HALS1併用系 に $\mathrm{TiO}_{2}$ を添加した場合も $\mathrm{BHT}$ 残存率は時間とともに低下し た. 特にアナターゼを用いた場合に低下は顕著であった。

\section{5 HALS 濃度の検討}

キノン系化合物生成への HALS1 濃度の影響を明らかに するため, BHT濃度を $5 \times 10^{-2} \mathrm{~mol} / \mathrm{L} に$ 固定し, HALS1 濃度を $1 \times 10^{-2}, 5 \times 10^{-2}, 1 \times 10^{-1}, 2 \times 10^{-1} \mathrm{~mol} / \mathrm{L}$ と変え, $120{ }^{\circ} \mathrm{C} て ゙ 24$ 時間加熱処理を行った. Figure 7 は スチルベンキノンに起因する吸収ピークの吸光度と HALS1 濃度の関係である. 吸光度はHALS1 濃度とともに 大きくなったことから，キノン系化合物の生成量は HALS1 濃度に比例することが明らかである。

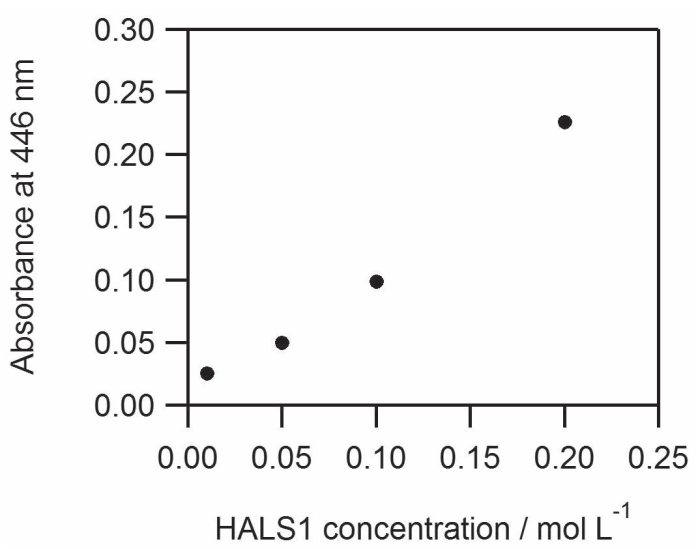

Figure 7 Relationship between absorbance at $446 \mathrm{~nm}$ after heating at $120^{\circ} \mathrm{C}$ for $24 \mathrm{~h}$ and HALS1 concentration of $(\mathrm{BHT} \cdot \mathrm{HALS} 1)$.

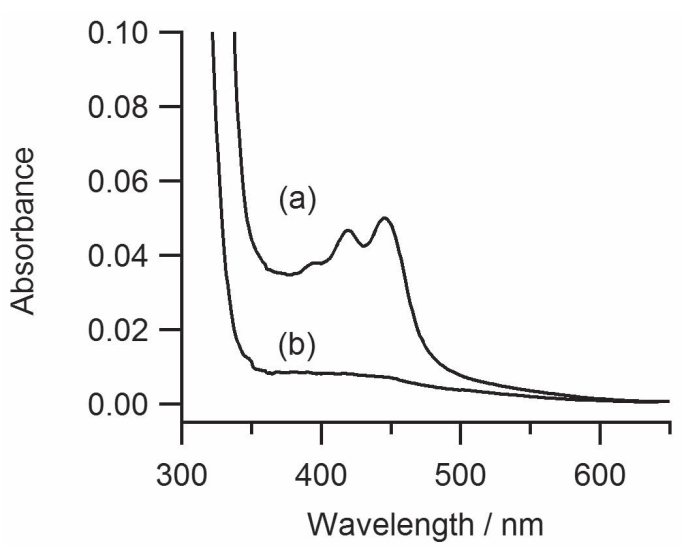

Figure $8 \mathrm{UV} / \mathrm{VIS}$ spectra for (a) (BHT·HALS1) and (b) (BHT·HALS2) after heating at $120^{\circ} \mathrm{C}$ for $24 \mathrm{~h}$.

HALS の酸化防止機構はHALS の基本骨格（>N-H，> $\left.\mathrm{N}-\mathrm{CH}_{3}\right)$ ではなく，ピペリジンが酸化されてニトロキシラ ジカル $(>\mathrm{NO} \cdot)$ を生成し, その後ニトロキシド $(>\mathrm{NO})$, ヒドロキシアミン (>NOH), およびアルコキシド（> NOR）のサイクルを繰り返すことでラジカル捕捉能を示 す23-26). しかしながら, HALSの基本骨格の N-置換基に より塩基性は異なるため, HALSの塩基性がBHTの酸化 に対して影響することも予想される，そこで，二級アミン であるHALS1 と三級アミンであるHALS2 を用いて 120 ${ }^{\circ} \mathrm{C} 24$ 時間の熱処理を実施した. Figure 8 はBH・HALS1 およびBHT·HALS2の熱処理後のUV/VISスペクトルで ある. HALS2 を併用した場合も可視光領域に吸収が認め られたが，その強度は著しく弱かった。したがって，塩基 性が高いほどBHTの酸化を促進すると考えられる。

\section{6 高分子材料での変色現象}

これまで，モデル系として $n$-デカン溶液中において BHTとHALS1 を併用した際の変色機構について議論し た。ここでは，PP中にBHTとHALS1 を配合した際の黄 変現象について検討した。

PP1〜PP5の試料は $90{ }^{\circ} \mathrm{C} 28$ 日間の熱処理で外観に変化

Table 4 Color difference and yellow index for PP compounds containing additives before and after heating at $90{ }^{\circ} \mathrm{C}$

\begin{tabular}{|c|c|c|c|c|c|c|c|}
\hline \multirow{2}{*}{ Sample } & & \multicolumn{2}{|c|}{$\begin{array}{c}\text { PP6 } \\
(\mathrm{BHT} \cdot \mathrm{HALS} 1)\end{array}$} & \multicolumn{2}{|c|}{$\begin{array}{c}\text { PP7 } \\
(\mathrm{BHT} \cdot \mathrm{HALS1} \cdot \text { rutile })\end{array}$} & \multicolumn{2}{|c|}{$\begin{array}{c}\text { PP8 } \\
(\mathrm{BHT} \cdot \mathrm{HALS1} \cdot \text { anatase })\end{array}$} \\
\hline & & pristine & $\begin{array}{l}\text { after heating } \\
\text { for } 28 \text { days }\end{array}$ & pristine & $\begin{array}{c}\text { after heating } \\
\text { for } 72 \mathrm{~h}\end{array}$ & pristine & $\begin{array}{l}\text { after heating } \\
\text { for } 72 \mathrm{~h}\end{array}$ \\
\hline \multirow{3}{*}{ Chromaticity } & $\mathrm{L}^{*}$ & 76.1 & 72.8 & 93.4 & 89.4 & 90.0 & 81.9 \\
\hline & $a^{*}$ & 1.0 & -1.4 & -0.6 & -5.6 & 0.1 & -5.3 \\
\hline & $\mathrm{b}^{*}$ & 4.1 & 13.0 & 3.3 & 24.0 & 6.3 & 52.9 \\
\hline \multirow{4}{*}{$\begin{array}{c}\text { Color } \\
\text { difference vs. } \\
\text { at pristine }\end{array}$} & $\Delta \mathrm{L}^{*}$ & - & -3.3 & - & -4.1 & - & -8.1 \\
\hline & $\Delta \mathrm{a}^{*}$ & - & -2.4 & - & -5.0 & - & -5.4 \\
\hline & $\Delta \mathrm{b}^{*}$ & - & 8.8 & - & 20.7 & - & 46.6 \\
\hline & $\Delta \mathrm{E}^{*}$ & - & 9.7 & - & 21.7 & - & 47.7 \\
\hline \multicolumn{2}{|c|}{ Yellow Index } & 10.5 & 26.9 & 5.7 & 37.1 & 12.3 & 75.8 \\
\hline
\end{tabular}




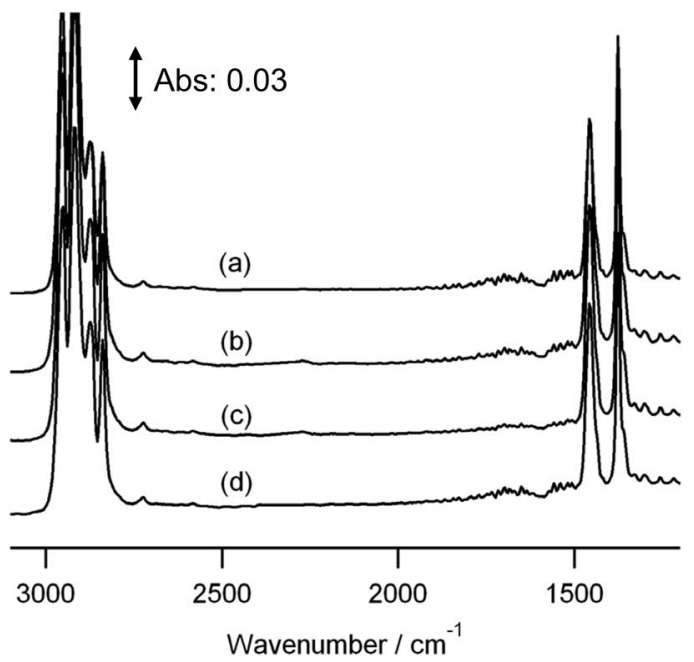

Figure 9 IR spectra for; (a) pristine PP, (b) PP6 (BHT·HALS 1) after heating at $90{ }^{\circ} \mathrm{C}$ for 28 days, (c) PP7 (BHT. HALS1-rutile) after heating at $90^{\circ} \mathrm{C}$ for $72 \mathrm{~h}$, and (d) PP8 (BHT·HALS1·anatase) after heating at $90{ }^{\circ} \mathrm{C}$ for $72 \mathrm{~h}$.

を示さなかったが，BHTとHALS1を配合したPP6は 28 日後変色していた。また，ルチルおよびアナターゼを配合 したPP7 およびPP 8 は 72 時間後にはすでに黄変した。 Table 4 は変色が観察された試料の色差を示している．熱 処理前後の YIを比較すると，PP6の $\Delta \mathrm{YI}$ は $16.4 ， \mathrm{PP} 7$ は 31.4, PP8は63.5でいずれも黄変が進行した。熱処理を行 ったPP6，PP7抢よびPP8のジクロロメタン抽出液は黄色 であったが，抽出残渣のPPは白色であった．熱処理後 PP6 抽出物の UV/VIS 測定では波長範囲350〜500 nm に 新たな吸収が観測された。 GC/MS 測定より，この変色物 質はキノン系化合物と同定した。

$\mathrm{PP}$ は劣化を生じると発色団のひとつである $\mathrm{C}=\mathrm{O}$ 基 $\left(1720 \mathrm{~cm}^{-1}\right)$ を生成し変色を生じることが知られている ${ }^{27)}$. そこで, 抽出残渣のPPをIR測定し劣化の有無を調查した. Figure 9 は未処理のPP打よび熱処理後のPP6，PP7 およ びPP8のIR スペクトルである。すべての試料において $1720 \mathrm{~cm}^{-1}$ 付近にピークは認められなかったことから， PP自身の劣化は進行していないと結論できる。さらに BHT と HALS1に $\mathrm{TiO}_{2}$ を配合すると変色の発現速度は速 くなり $\mathrm{TiO}_{2}$ が触媒効果を示すことが明瞭であった. BHT と HALS1を併用した場合に発現する変色現象および $\mathrm{TiO}_{2}$ の触媒効果は高分子材料中でも $n$-デカン溶液中と同様であ った。

\section{4. 結論}

フェノール系酸化防止剤BHT と光安定剂HALSを併用 して熱処理を行うと，HALSによってBHTの酸化が促進 されて変色するが，HALSによるBHTの変色は，HALS の濃度が高く，また，塩基性が強いほど促進される，さら
に，HALSによるBHTの酸化において， $\mathrm{TiO}_{2}$ ，特にアナ ターゼは触媒作用を示して変色を促させることが明らかと なった。これら変色挙動は $n$-デカン溶液中でも高分子材料 中でも同様の挙動を示すことが確認された。

\section{References}

1 ) Cook, C. D.: J. Org. Chem., 18, 261 (1952)

2 ) Cook, C. D.; Woodworth, R. C.: J. Am. Chem. Soc., 75, 6242 (1953)

3 ) Cook, C. D.; Nash, N. G.; Flanagan, H. R.: J. Am. Chem. Soc., 77, 1783 (1955)

$4)$ Yohe, G. R.; Dunbar, J. E.; Pedrotti, R. L.; Scheidt, F. M.; Lee, F. G. H.; Smith, E. C.: J. Org. Chem., 21, 1289 (1956)

5 ) Smeltz, K. C.: Text. Chem. Color., 15, 17 (1983)

6 ) Pospisil, J.: Polym. Degrad. Stab., 20, 181 (1988)

7 ) Yachigo, S.; Sasaki, M.; Ishii, T.; Tanaka, S.: Polym. Degrad. Stab., 37, 99 (1992)

8 ) Yachigo, S.; Kojima, F.; Sasaki, M.; Ida, K.; Tanaka, S.; Inoue, K.: Polym. Degrad. Stab., 37, 107 (1992)

9 ) Yachigo, S.; Ida, K.; Sakaki, M.; Inoue, K.; Tanaka, S.: Polym. Degrad. Stab., 39, 317 (1993)

10) Latesky, S. L.; Keddington, J.; Mcmullen, A. K.; Rothwell, I. P.; Huffman, J. C.: Inorg. Chem., 24, 995 (1985)

11) Klemchuk, P. P.; Horng, P. L.: Polym. Degrad. Stab., 34, 333 (1991)

12) Epacher, E.; Fekete, E.; Gahleitner, M.; Pukanszky, B.: Polym. Degrad. Stab., 63, 489 (1999)

13) Pospisil, J.; Habicher, W. D.; Pilar, J.; Nespurek, S.; Kuthan, J.; Piringer, G. O.; Zweifel, H.: Polym. Degrad. Stab., 77, 531 (2002)

14) Vyprachticky, D.; Pospisil, J.:Sedlar, J.: Polym. Degrad. Stab., 27, 227 (1990)

15) Habicher, W. D.; Bauer, I.; Scheim, K.; Rautenberg, C.; Loback, A.; Yamaguchi, K.: Macromol. Symp., 115, 93 (1997)

16) Barret, J.; Gijsman, P.; Swagten, J.; Lange, R. F. M.: Polym. Degrad. Stab., 76, 441 (2002)

17) Yamashita, H.; Ohkatsu, Y.: Polym. Degrad. Stab., 80, 421 (2003)

18) Yamashita, H.;Kawaguchi, A. W.; Ohkatsu, Y.: J. Jpn. Petrol. Inst., 49, $294(2006)$

19) Ohkatsu, Y.; Fujiwara, T.: J. Jpn. Petrol. Inst., 50, 87 (2007)

20) Ohkatsu, Y.: J. Jpn. Petrol. Inst., 51, 191 (2008)

21) Ohkatsu, Y.: Nippon Gomu Kyokai $121^{\text {th }}$ Gomu Gijutsu Symposium Yoshishu, 1 (2006)

22) Ohkatsu, Y.: Nippon Gomu Kyokai $130^{\text {th }}$ Gomu Gijutsu Symposium Yoshishu, 1 (2007)

23) Klemchuk, P. P.; Gande, M. E.: Polym. Degrad. Stab., 22, 241 (1988)

24) Klemchuk, P. P.; Gande, M. E.; Cordola, E.: Polym. Degrad. Stab., 27, 65 (1990)

25) Step, E. N.; Turro, N. J. ; Gande, M. E.; Klemchuk, P. P.: Macromolecules, 27, 2529 (1994)

26) Gugumus, F.: Polym. Degrad. Stab., 34, 205 (1991)

27) Osawa, Z.: Degradation and Stabilization of Polymers, Musashino create, Tokyo, p.46 (1992)

\section{日本語表記参考文献}

21）大勝靖一：日本ゴム協会第 121 回ゴム技術シンポジウム要旨集, 1 (2006)

22）大勝靖一：日本ゴム協会第130回ゴム技術シンポジウム要旨集, 1 (2007)

27）大澤善次郎：高分子の劣化と安定化, 武蔵野クリエイト, 東京, p.46 (1992) 